\title{
Investigation of the Role of CpG Methylation in Epithelial Mesenchymal Transition Master Genes in a Chemoresistant Ovarian Cancer Cell line
}

\section{Yaman Alghamian}

Faculty of Sciences-Damascus University

Chadi Soukkarieh

Faculty of Sciences-Damascus University

Abdul Qader Abbady

Atomic Energy Commission of Syria

Hossam Murad ( $\nabla$ hmurad@aec.org.sy)

Atomic Energy Commission of Syria

\section{Research Article}

Keywords: Ovarian cancer, CpG methylation, epithelial mesenchymal transition (EMT), Chemoresistant

Posted Date: June 2nd, 2021

DOl: https://doi.org/10.21203/rs.3.rs-579729/v1

License: (a) (i) This work is licensed under a Creative Commons Attribution 4.0 International License.

Read Full License 


\section{Abstract}

Ovarian cancer is one of the commonly diagnosed cancers among women. Chemoresistant is an essential reason for treatment failure and high mortality. Emerging evidence connects epithelial mesenchymal transition (EMT) like changes and acquisition of chemoresistance in cancer. DNA methylation influences cellular processes including EMT. Here, we investigate EMT like changes in cisplatin-resistant A2780 ovarian cancer cells (A2780cis), and we study the DNA methylation role in EMT master genes regulation. Cell viability assay was carried to test the sensitivity of A2780, and A2780cis human cancer cell lines to cisplatin compared to other cancer cell lines. Differential mRNA expression of EMT markers using qPCR was conducted to investigate EMT like changes. The role of $\mathrm{CpGs}$ methylation in gene expression regulation was investigated by 5-azacytidine (5-aza) treatment. DNA methylation changes in EMT genes were identified using Methylscreen assay between A2780 and A2780cis cells. A2780cis maintains its cisplatin tolerance ability and exhibits phenotypic changes congruent with EMT. Methylscreen assay and qPCR study revealed DNA hypermethylation in promoters of epithelial adhesion molecules $C D H 1$ and EPCAM in A2780cis compared to the cisplatin-sensitive parental cells, these changes were concomitant with gene expression down-regulation. DNA hypomethylation associated with transcription up-regulation of the mesenchymal marker TWIST2 was observed in the resistant cells. Azacytidine treatment confirmed the DNA methylation role in the regulation of gene expression of CDH1, EPCAM and TWIST2 genes. A2780cis cell line undergoes EMT like changes, and EMT master genes are regulated by DNA methylation. A better perception of the molecular alterations which correlate with chemoresistance may lead to therapeutic benefits such as chemosensitivity restoration.

\section{Introduction}

Ovarian cancer is one of the deadliest gynecologic cancer in females ${ }^{1}$. Patients with ovarian cancer have a poor prognosis, and a high mortality rate ${ }^{2}$. The low survival rate of ovarian cancer is due to metastasis and acquiring of chemotherapies resistance ${ }^{3}$. Cisplatin (cis-diamminedichloroplatinum [II]) is a platinum compound used to treat many solid tumors including ovarian cancer ${ }^{4,5}$. Cisplatin induces DNA lesions and activates several signaling pathways such as DNA repair mechanisms ${ }^{6}$. When DNA damage fails to be repaired, cells undergo apoptosis and $\mathrm{die}^{7}$. Drug resistance is the main obstacle that limits treatment effectiveness ${ }^{8}$. The mechanisms that underlie platinum drug resistance are multifactorial. Several cellular processes have been identified as responsible for the resistant phenotype, including alterations in drug influx or efflux, DNA repair, cell cycle and apoptosis ${ }^{9,10}$. Recent evidence suggests that epithelialmesenchymal transition (EMT) processes may have a role in the development of chemoresistance. EMT is a cellular procedure where epithelial cells miss their cell-cell adhesion, cell polarity and gain metastasis capability ${ }^{11}$. The molecular signatures of EMT are loss of epithelial cell markers $C D H 1$ and mesenchymal markers up-regulation including EMT transcription factors SNAIL and TWIST ${ }^{12,13}$. EMT like changes has been reported in various chemoresistant cancer such as gastric cancer ${ }^{14}$ non-small cell lung cancer ${ }^{15,16}$, nasopharyngeal carcinoma cells ${ }^{17}$, breast cancer cells ${ }^{18,19}$, and ovarian cancer cells ${ }^{20,21}$. 
Multiple epigenetic events, such as DNA methylation, histone modifications, and non-coding RNA, have been described to contribute to the acquisition of chemoresistance ${ }^{22-24}$. DNA methylation is the most well-known epigenetic mechanism that occurs at CpGs islands that influence cellular processes by regulating gene expression ${ }^{25}$. Commonly, gene promoter hypermethylation is associated with reduced expression, while hypomethylation increases gene expression ${ }^{26,27}$. DNA methylation changes at CpG islands associated with transcriptional

silencing have been stated in cisplatin-resistant cancer cell lines ${ }^{28-30}$. For example; DNA methylation of several genes including (ARMCX2, COL1A1, MDK, MEST, MLH1, KLF4, ST3GAL5, SYNE1, CXCL8, HERC5, FOSL 1, and ARRDC4) was linked to ovarian cancer initiation and chemotherapy resistance ${ }^{31,32}$. A study in ovarian and breast cancer cell lines with doxorubicin tolerance described methylation changes in genes that contributed to chemoresistance and identified hyper-methylation of $C D H 1, B R C A 1$, SULF2 and $D N A J C 15$ besides hypo-methylation of $A P C, A B C B 1$ and $H I C 1$ genes ${ }^{23}$. Based on these considerations, the need to study the linkage between EMT and DNA methylation regulation has become pivotal to understand the chemoresistant phenotype.

The present study aimed to assess the morphological and transcriptional changes in cisplatin resistant A2780 ovarian cancer cell line in relation to EMT, and comparing these changes with different types of cisplatin-resistant cell lines. Our study focused on $\mathrm{CpG}$ methylation changes that regulate EMT master genes in A2780 chemoresistant cells.

\section{Results}

\section{Cancer cells display different morphological phenotypes}

We observed the morphological characteristics of the different cancer cell lines sensitive or resistant to chemotherapy during exponential growth, i.e. shape, size and growth pattern of the cells during culture. A2780 cells formed clusters with small round-shaped cells consistent with an epithelial phenotype. In contrast, A2780cis cells were larger, more elongated and were frankly polygonal (Fig. 1A).

These observations were compared with the morphological of MDA-MB-231 and T98G cell lines as they were known to be resistant to chemotherapy ${ }^{33-35}$. Figure 1B shows that MCF7 cells have small squamous epithelial appearance, whereas MDA-MB-231 cells have spindle-like morphology. U-87 MG and T98G cells exhibit spindle like morphology, T98G cells showed a larger and more elongated cell shape compared to U-87 MG (Fig. 1C). These observations suggest that this dissimilar cellular shape is possibly associated with alteration in the EMT process.

\section{Dissimilar shaped cancer cell lines have different cisplatin tolerance capacity}

MTT assay was performed to assess the effect of cisplatin on different human cancer cell lines. Cells were treated with increased concentrations of cisplatin for $24 \mathrm{hrs}$. Concentration-dependent effect of cisplatin on different cells was observed. $\mathrm{IC}_{50}$ value in $\mathrm{A} 2780$ cis cells was 4 times higher than the parental 
cell line's $\mathrm{IC}_{50}$, which suggested that the A2780cis cells were more resistant to cisplatin-induced cytotoxicity compared with A2780 cells and had still maintained cisplatin resistance (Fig. 2A). Results in Fig. $2 \mathrm{~B}$ show that the $\mathrm{IC}_{50}$ value for MDA-MB-231 cells is six times greater than $\mathrm{IC}_{50}$ for MCF7 cells. Figure $2 \mathrm{C}$ shows the differences in cisplatin sensitivity between U-87 MG and T98G cell lines, the difference in $\mathrm{IC}_{50}$ values was the least among other cell line models used in this study. IC $\mathrm{C}_{50}$ in $\mathrm{T} 98 \mathrm{G}$ cells was 1.3 times higher than U-87 MG's IC 50 . The IC 50 results were summarized in (Fig. 2D).

\section{MDR1 Expression increases in the resistant variant A2780cis cell line}

To determine whether cisplatin resistance in the A2780cis cells is associated with increased expression of $A B C$ transporters genes, mRNA expression level of the following genes was assessed: MDR1(multidrug resistance protein 1 gene), MRP1 (MDR-related protein 2) and MRP2 (MDR-related protein 2) using qRTPCR. Figure 3 showed that there was a statistically significant increase of $M D R 1$ transcript level (5.8 fold) in A2780cis cell line compared to the parental cell line. On another hand, MRP1 and MRP2 expression did not significantly change in A2780 and A2780cis cell lines.

\section{Cisplatin resistant cancer cells have molecular changes consistent with EMT}

To determine whether the gaining of cisplatin resistance promotes specific molecular alterations corresponding with EMT in ovarian cancer, qRT-PCR was performed to investigate EMT-related biomarkers expression. Results showed that the expression of epithelial markers, $C D H 1$ and $E P C A M$, was significantly reduced by 0.02 and 0.013 fold, respectively in the A2780cis cells compared with A2780 cells. The expression of mesenchymal markers, SNAIL, and TWIST2, were higher by 4.9 and 20.3 fold respectively in the A2780cis cells compared with the parental cell line (Fig. 4A). Based on these observations, A2780cis cells may be considered to have a mesenchymal like phenotype.

We also compared these changes in transcriptional levels in MDA-MB-231 and T98G cells, to figure if the changes observed in A2780cis are common in other cancer cells resistant to therapy. The same molecular changes of EMT markers observed in A2780cis cells were detected in MDA-MB-231 in comparison with MCF7, CDH1 and EPCAM genes were decreased 0.5 and 0.006 fold respectively. These decreases were associated with up-regulation of EMT genes SNAIL and TWIST2 (2.6 and 40732 fold) (Fig. 4B). The same molecular changes were observed in EMT markers; $C D H 1$ and EPCAM were down-regulated (0.046 and 0.2 fold, respectively) in T98G the more resistant cell line, whereas SNAIL and TWIST2 (88.5, 76 fold respectively) were up-regulated (Fig. 4C). We notice a significant overlap in expression profiles of EMT genes between resistant cancer cell lines, proposing a shared mechanism associated with resistance to therapy.

\section{5-azacytidne treatment up-regulates expression of EMT-related genes in A2780 cell line}

To identify the epigenetically regulated genes from the gene set that expressed differentially between A2780 cell line and the resistant variant, we analyzed gene expression by qPCR after azacytidine treatment. As shown in Fig. 5 azacytidine treatment significantly increased the expression of $C D H 1$, 
EPCAM, SNAIL, and TWIST2 genes, by $7.8,9.26,5.24$, and 4 fold respectively. This suggests that DNA methylation may be essential in the regulation of the expression of these genes in this cell line.

\section{Acquisition of cisplatin resistance in A2780 cell line induced aberrant DNA Methylation in EMT-related genes}

Methylscreen assay was used to determine the DNA methylation profile in genes that differentially expressed between A2780 and resistant variant cells and that expression increased after azacytidine treatment. PCR primers were designed to amplify genomic DNA at the TSS associated CpG islands of these genes. The PCR amplicons ranged from $151 \mathrm{bp}$ to $523 \mathrm{bp}$ in length. These amplicons contained different site numbers for $\mathrm{Hhal} / \mathrm{Hpall}$, Acil and McrBC. Size of DNA fraction amenable to digestion (analytical window) determine assay sensitivity and it was represented by $\Delta \mathrm{Ct}$ between the Rsd and R0 reactions and it ranged from 3.2 to 13.6 .

The kinetic profiles obtained from each of the four assays (CDH1, EPCAM, SNAIL, TWIST2) obtained from A2780 and A2780cis DNA are displayed (Figs. 6B, 7B, 8B, 9B). The data depict results from cell lines; each genome's amplification is color coded by their digestion treatment: mock restriction (black), MSRE restriction (blue), MDRE restriction (red) and a DD (green). The charts display the result of each assay as a percentage of each portion of DNA according to its methylation state, i.e., the unmethylated fraction, intermediate methylated and hypermethylated fraction (Figs. 6C, 7C, 8C, 9C). Results from CDH1 assay revealed a $13.47 \%$ hypermethylation in the densely methylated portion after the acquisition of cisplatin resistance. The methylation of the region from (-306 to $-82 \mathrm{bp}$ ) which contains [7 Acil, 3 Hpall and 7 $\mathrm{MCrBc}$ restriction sites increased from $24.76 \%$ to $39.11 \%$ in A2780 and A2780cis, respectively (Fig. 6). On the other hand, Fig. 7 shown that the CpGs in region (-463 to $-296 \mathrm{bp}$ ) of EPCAM gene that contains [8 Acil, $4 \mathrm{Hhal}$, and $7 \mathrm{MCrBc}$ ] restriction sites in A2780 DNA was $73.15 \%$ unmethylated, $0 \%$ intermediate methylated and $26.85 \%$ densely methylated. In A2780cis the unmethylated portion value was decreased and CpGs were gained methylation by $23.67 \%$. Methylscreen assay of SNAIL gene revealed that (-688 to $-165 \mathrm{bp}$ ) region is unmethylated in A2780 cell line and there are no significant differences in methylation between A2780cis and its parental cell line (Fig. 8). The methylation analysis of TWIST2 gene revealed that the region from ( -328 to $-177 \mathrm{bp}$ ) that contains [6 Acil, $3 \mathrm{Hhal}$, and $4 \mathrm{MCrBc}$ ] restriction sites was 3.37 $\%$ hypermethylated, $88.98 \%$ intermediate methylated and $7.65 \%$ unmethylated. In A2780cis the intermediate methylated portion value was decreased compared to A2780 and the fraction of unmethylated DNA was $21.76 \%$ in A2780cis (Fig. 9).

\section{Discussion}

Ovarian cancer ranks as one of the most common causes of cancer deaths among females ${ }^{1}$. Patients suffering from ovarian cancer have a poor prognosis, with a low survival rate ${ }^{3}$. High mortality of ovarian cancer is mainly due to metastasis and the evolution of resistance to chemotherapies ${ }^{2}$. Cisplatin is a cornerstone of the treatment regime for many solid tumors including ovarian cancer ${ }^{4,5}$. However, its clinical effectiveness is influenced by acquiring tumor cells chemoresistant ${ }^{8}$. Many studies concentrated on the molecular mechanisms mediating the development of cisplatin resistance and lots have been 
characterized including decreased cellular uptake of the drug, increased drug efflux, enhanced DNA damage repair capacity, and anti-apoptotic signaling 9,10 .

In this study, we demonstrated that the A2780cis cell line still has the tolerance capacity to cisplatin and its resistance accompanied by an increase in the expression of MDR1 (Fig. 3). This marker seems to be a universal cellular response marker to chemotherapy in various cancer. A high expression level of MDR1 was detected in the cisplatin, paclitaxel and doxorubicin resistant variant of A2780 cells and different resistant cell lines derived from ovarian cancer ${ }^{36-39}$. Several studies have shown conflicting results about the differential expression of MRP1 and MRP2 genes between sensitive and resistant ovarian cancer cell lines, and the ability of these changes to represent the chemoresistance ${ }^{38,40}$. Recently, epithelialmesenchymal transition (EMT) was implicated as a core mechanism mediating drug resistance ${ }^{41}$. EMT is defined as a biological mechanism characterized by loss of cell adhesion, as well as loss of cell polarity and gain motility ${ }^{11}$. EMT results in changes in cell morphology associated with alterations in epithelial and mesenchymal markers expression ${ }^{42}$. EMT like phenotype has been reported in chemoresistant variant cell lines generated upon multiple rounds of chemotherapy treatment such as; cisplatin resistant ovarian cancer cells (TOV-112D, MDAH, OVSAHO, SKOV-3/DDP, OVCAR3/DDP and A2780CP) $43-46$, A2780/PTX, NOS-PR, TAOV-PR, and SKOV-PR paclitaxel resistant ovarian cancer cells ${ }^{20,21}$. Also, chemotherapeutic resistance promotes EMT like changes in other cancer cell lines, including non-small cell lung cancer ${ }^{15,16}$, gastric cancer ${ }^{14}$ nasopharyngeal carcinoma cells ${ }^{17}$, and breast cancer cells ${ }^{18,19}$. In this present study, we demonstrate that the resistant variant A2780cis cell line underwent EMT. This was confirmed by noticing a morphological change from small round shaped to elongated and polygonal shaped cells and changes in molecular markers of EMT; significant reduction in CDH1 and EPCAM and upregulation of the transcription factors, SNAIL and TWIST2 (Fig. 1 and Fig. 4).

Multiple studies have shown that naïve cancer cell lines and clinical tumor samples can be divided according to their mesenchymal/epithelial phenotype, this sorting could determine the sensitivity to chemotherapy in various cancers including ovarian, breast, and lung cancers ${ }^{47-52}$. From this observation, we compared the EMT like changes detected in A2780cis with changes in breast and glioma cell line models known as resistant cancer cells ${ }^{33-35}$. We used MDA-MB-231 and T98G cancer cells as other models of cell lines to figure if the acquired changes observed in A2780cis are common in other cancer cells, resistant to therapy. We detect the same molecular alteration consistent with morphological in cisplatin resistant MDA-MB-231 cells compared with the sensitive cells MCF7. The same transcripts changes in CDH1, EPCAM, SNAIL and TWIST2 genes also detected in chemoresistant T98G cell line in comparison with the less cisplatin tolerance cells U-87-MG (Fig. 2). This indicates the importance of $C D H 1$, EPCAM, SNAIL and TWIST2 genes in EMT mechanism associated with cisplatin resistance.

$C D H 1$ is $\mathrm{Ca}^{2+}$ dependent adhesion molecule that binds by its extracellular domain to $C D H 1$ on the adjacent cell creating a bridge between the cell's cytoskeletons ${ }^{53}$. Many studies revealed that $C D H 1$ downregulation may be associated with cancer cells resistant to chemotherapy that can be attributed to the EMT mechanism activation ${ }^{23,54}$. Acquisition of paclitaxel chemoresistant induces EMT phenotypic 
changes and $C D H 1$ in down-regulation in NOS-PR and A2780/PTX ovarian cancer cell line ${ }^{20,21}$. EPCAM is an epithelial cell surface transmembrane glycoprotein that mediates homophilic cell-cell adhesion without $\mathrm{Ca}^{2+}$ dependent ${ }^{55,56}$. In ovarian cancer cells, EPCAM upregulation is connected to a more favorable prognosis and more effective platinum-based therapy ${ }^{57}$. Galle et al, found EPCAM expression is downregulated in addition to $\mathrm{CDH} 1$ in resistant variant cancer cells due to EMT process activation ${ }^{30}$. EMT transcription factors such as $S N A I L$ are considered as direct repressors of $C D H 1$ as they bind to E-boxes existing on the $C D H 1$ promoter ${ }^{58-60}$. Hojo, et al, observed that ovarian cancer cell lines OVCAR8 and COV318 with high Snail/CDH1 showed more motile and cisplatin resistant phenotypes than OVSAHO and Kuramochi cell lines that have low SNAIL/CDH1 ${ }^{47}$. TWIST2 is considered as a direct repressor of $C D H 1$, it can bind directly on E-boxes existing on the $\mathrm{CDH} 1$ promoter to suppress its expression and it can repress $C D H 1$ expression indirectly through activation of other signaling pathways ${ }^{61}$. Studies show that TWIST2 expression is a prognostic indicator for overall survival and disease-free survival and its overexpression correlates with poor prognosis and is associated with $\mathrm{CDH} 1$ down-regulation giving mesenchymal cell phenotype on ovarian cancer tumors ${ }^{62,63}$. Wang et al, demonstrate that TWIST2 plays a critical role in the cisplatin resistance of ovarian cancer. They found that TWIST2 expression up-regulated in resistant variant $\mathrm{C} 13 \mathrm{~K}$ ovarian cancer cell line compared to the cisplatin sensitive ovarian cancer cell line OV2008 64.

DNA methylation is one of the best described mechanisms of epigenetic that regulate gene expression. Aberrant DNA methylation is observed in cancers in CpG dinucleotides clustered around the TSS of genes, called $\mathrm{CpG}$ islands, leading to gene expression dysregulation ${ }^{65}$. Upon initiation of EMT, DNA methylation of the genome selectively undergoes $\mathrm{CPG}$ site methylation changes, which regulate transcription of EMTrelated genes ${ }^{23,30,66,67}$. In our study, we investigate the role of methylated $\mathrm{CpG}$ islands in the modulation of gene expression of EMT regulated genes in A2780 cancer cell lines. DNA methyltransferase inhibitor 5aza induces gene expression of CDH1, EPCAM, SNAIL, and TWIST2 which indicate that these genes may be regulated by DNA methylation. Chang et al, used gene expression profiling after cancer cells treatment with 5-azadeoxycytidine, they identified genes that were dysregulated in cisplatin resistant cancer cells and reactivated by the DNA methyltransferase inhibitor ${ }^{68}$. Here, we found that epithelial gene promoters $C D H 1$ and EPCAM became significantly more methylated in A2780cis compared to the parental cell line. These promoter methylation changes correlate with significant gene expression down-regulation. Boettcher et al, profiled DNA methylation of 800 selected CpG islands and identified hypermethylation in $C D H 1 \mathrm{CpG}$ islands in breast and ovarian doxorubicin resistance cancer cells ${ }^{23}$. EPCAM overexpression has been linked to promoter hypomethylation EPCAM-negative cells treated with a DNA methyltransferase inhibitor prompted EPCAM expression in various cancer types including ovarian cancer ${ }^{69-71}$. A recent study reported consistent methylation changes across multiple cancer cell lines differed in chemoresistant. Specifically, hypermethylation of epithelial marker genes such as $C D H 1$ and EPCAM promoters and hypomethylation of mesenchymal marker genes such as SNAIL in resistant versus parental cell lines ${ }^{30}$. Analysis of $S N A I L$ promoter region predicted a CpG island surrounding the TSS, we examined the DNA methylation status in the genomic region (-688 to $-165 \mathrm{bp})$, we cannot observe any methylation in 
CpGs located in this region of SNAIL promoter in A2780 and its resistant variant cells, although there were changes in SNIAL expression between the two cell lines and after azacytidine treatment. Literature has described changes in the histone modifications regulating SNAIL gene expression ${ }^{72}$. Single study described changes in the methylation of $\mathrm{CpG}$ island located in the first intron after $1000 \mathrm{pb}$ from TSS in EMT models of cancer cells ${ }^{73}$. Maybe the differential methylation in SNAIL gene could be identified in the intron region in A2780 cell line. CpGs island of mesenchymal transcription factor TWIST2 promoter showed DNA hypomethylation in A2780cis compared to the parental cells, this hypomethylation coincides with gene expression down regulation due to EMT activation. TWIST2 methylation changes were observed in various cancer such as colorectal cancers, prostate cancer, and chronic lymphocytic leukemia, this epigenetic event might be the underlying mechanism for TWIST2 transcriptional regulating ${ }^{74,75}$.

In conclusion, we have shown in this study that, the gain of cisplatin resistance in cancer cells is accompanied by EMT-like changes at the morphological and molecular levels. We show that DNA methylation changes of CDH1, EPCAM and TWIST2 genes underlie the resistant induced EMT in ovarian cancer cell lines. Further evaluation is needed in future clinical studies to determine potential EMT associated epigenetic biomarkers for resistant phenotypes.

\section{Methods}

\section{Cell Culture}

Human ovarian cancer cell lines A2780 (cisplatin sensitive human epithelial ovarian cancer cell line) and A2780cis (the resistant variant), human breast cancer cell lines MCF7 and MDA-MB-231, and human glioblastoma cancer cell lines U-87 MG and T98G were purchased from European Collection of Authenticated Cell Cultures (England). A2780 and A2780cis cell lines were grown in complete RPMI-1640 medium containing $10 \% \mathrm{FBS}, 2 \mathrm{mM}$ glutamine, $0.1 \mathrm{mg} / \mathrm{ml}$ each of penicillin and streptomycin. To maintain A2780cis resistance to cisplatin, $1 \mu \mathrm{M}$ of cisplatin (Sigma-Aldrich, St. Louis, USA) was added to the media every 3 passages. MCF7 and MDA-MB-231 cell lines were grown in EMEM containing $10 \%$ FBS, $2 \mathrm{mM}$ glutamine, $1 \%$ non-essential amino acids (NEAA), $0.1 \mathrm{mg} / \mathrm{ml}$ each of penicillin and streptomycin. U87 MG and T98G cell lines were cultured in EMEM, 2 mM Glutamine, $10 \%$ FBS and $1 \%$ Sodium Pyruvate (NaP). All cell cultures were kept in $5 \%(\mathrm{v} / \mathrm{v}) \mathrm{CO}_{2}$ humidified atmosphere at $37^{\circ} \mathrm{C}$ (Binder, Germany). Morphological phenotypes of cell lines were assessed when the cell density was up to $70 \%$ confluence using Eclipse TS100 inverted light microscope (Nikon, Japan).

\section{Cell Viability Assay}

Cells were plated into 96 -well-plates $\left(1 \times 10^{4}\right.$ cells/well) for MTT assay and allowed to attach O/N. Different concentrations of cisplatin were used to treat cells for 24 hrs. MTT solution (Roche, Germany) was added to each well and incubated for $4 \mathrm{hrs}$ at $37^{\circ} \mathrm{C}$. Then absorbance values were measured at 550 $\mathrm{nm}$ using Multiskan Ascent absorbance plate reader (Thermo Labsystems, Germany). Cell viability determined as following: 
Cell viability $(\%)=($ average OD value of experimental group/average OD value of control group $) * 100 \%$

\section{Gene expression analysis by qRT-PCR}

Total RNA was extracted from A2780, A2780cis, MCF7, MDA-MB-231, U-87 MG, T98G cell lines and from A2780 treated with 5-azacytidine (5-aza) using the RNeasy Mini kit (Qiagen, Germany). First-

strand cDNA synthesis was carried out from $3 \mu \mathrm{g}$ total RNAs were reverse transcriptase to cDNAs using MMLV reverse transcriptase (Invitrogen, USA) for $2 \mathrm{hrs}$ at $37^{\circ} \mathrm{C}$. To calculate the relative expression of EMT regulating genes; (CDH1, EPCAM, SNAIL 1, TWIST2), and ABC transporters (ATP-binding cassette transporters) genes; (MDR1-multidrug resistance protein 1 gene, MRP1-MDR1-related protein 1, MRP2MDR-related protein 2), quantitative real-time PCR was performed using Maxima ${ }^{\mathrm{TM}} \mathrm{SYBR}^{\mathrm{TM}}$ Green/ROX $2 \mathrm{x}$ qPCR Master Mix (Thermo Scientific, USA) for 40 amplification cycles using StepOne ${ }^{\text {TM }}$ Real-Time PCR System (Applied Biosystems, USA). Relative transcript fold changes were calculated using the $\triangle \triangle \mathrm{Ct}$ method with $G A P D H$ as a reference gene. All reactions were run in triplicate. Primers sequences are detailed in Table 1.

\section{5-Azacytidine treatment}

In order to select the candidate genes for the methylation study, A2780 cells were cultured and treated with $0.1 \mathrm{mM}$ 5-Azacytidine (Sigma-Aldrich, USA). Culture medium was removed every $24 \mathrm{hrs}$ and replaced by a fresh medium containing $0.1 \mathrm{mM} \mathrm{5-aza.} \mathrm{Treated} \mathrm{and} \mathrm{mock} \mathrm{treated} \mathrm{cells} \mathrm{were} \mathrm{collected} \mathrm{after} 7$ treatment days and total RNAs were extracted as described above.

\section{DNA extraction}

Genomic DNAs from A2780 and A2780cis cells were extracted using the QIAamp DNA Mini kit (Qiagen, Germany) according to the manufacturer's instructions. Isolated DNAs were quantified using NanoVue Plus (GE Healthcare Life Sciences, Germany).

\section{Methylscreen assay}

Quantitative PCR-based methylation analysis (Methylscreen assay) was performed to analyze DNA methylation of genes that have differential expression between A2780 and the resistant variant cells and that expression increased after 5-aza treatment. Methylscreen assay is based on combined restriction digestion of DNA with methylation sensitive and methylation dependent restriction enzymes, MSRE and MDRE respectively ${ }^{76}$. Genomic DNA of A2780 and A2780cis cells were divided into four parts and treated with different digestions: (1) Rs: two methylation-sensitive enzymes MSRE (Hhal + Acil) or (Hpall + Acil) depending on the frequency of their restriction sites within the studied fragments, which are cutting only unmethylated DNA, (2) Rd: one methylation-dependent restriction enzyme McrBC (MDRE), which is cutting only methylated DNA or (3) Rsd: both MSRE and MDRE enzymes (double digest, DD), and (4) R0: neither MSRE nor MDRE (mock control). Each $50 \mathrm{ml}$ reaction contained $1 \mathrm{mg}$ of gDNA, 1x CutSmart Buffer, $100 \mathrm{\mu g} / \mathrm{mL}$ BSA, $1 \mathrm{mM}$ guanosine-5'-triphosphate, $3 \%$ glycerol and $10 \mathrm{U}$ of each enzyme used in restriction reaction, 50 \% glycerol was used instead of enzymes in mock reaction in order to keep 
restriction digest cocktail homogeneity. Digestions were incubated at $37^{\circ} \mathrm{C}$ for $6 \mathrm{hrs}$ followed by inactivation of the enzymes at $65^{\circ} \mathrm{C}$ for $20 \mathrm{~min}$. The enzymes, CutSmart Buffer, BSA, and guanosine $-5^{\prime}-$ triphosphate were purchased from New England Biolabs, USA. Restricted samples were analyzed by qPCR with locus-specific PCR primers and SYBR Green dye. An in-silico analysis was performed using EMBOSS Cpgplot sequence analysis tool (https://www.ebi.ac.uk/Tools/seqstats/emboss_cpgplot/) from European Bioinformatics Institute (EMBL-EBI) to identify the $\mathrm{CpG}$ sites associated with the proximal promoter and transcription start site (TSS) for four genes. Sets of locus-specific PCR primers were designed to amplify gDNA at proximal CpG located within $1000 \mathrm{bp}( \pm)$ of the transcription start site for each gene. Primers sequences, genomic loci, numbers of $\mathrm{CpGs}$ nucleotides and number of restriction sites contained in amplified amplicons are listed in Table 2. The PCR amplification was performed in $20 \mathrm{ml}$ volume with 10 $\mathrm{ml}$ Maxima ${ }^{\mathrm{TM}}$ SYBR $^{\mathrm{TM}}$ Green/ROX 2x qPCR Master Mix (Thermo Scientific, USA), $300 \mathrm{nM}$ of each primer and $2 \mathrm{ml}(40 \mathrm{ng})$ of digested template DNA using the qPCR System. The PCR conditions were as follows: $95^{\circ} \mathrm{C}$ for $10 \mathrm{~min}$, and 45 cycles of $95^{\circ} \mathrm{C}$ for $1 \mathrm{~min}$ and temperature for optimized annealing for $1 \mathrm{~min}$. Amplification for each sample was performed in triplicate in a 48-well plate. All primer pairs were tested to identify the annealing temperature for optimal efficiency and melting curve analysis was conducted after the reaction to verify the amplification of the desired products.

\section{Calculations of DNA Methylation Occupancy}

The Ct values from RO, Rs, Rd and Rsd, reactions were used to calculate the initial amount of DNA in each digest before PCR as following:

$\mathrm{CMs}=2^{-\mathrm{Ct}(\mathrm{Rs})} ; \mathrm{CRd}=2^{-\mathrm{Ct}(\mathrm{Rd})} ; \mathrm{CRsd}=2^{-\mathrm{Ct}(\mathrm{Rsd})} ; \mathrm{CRO}=2^{-\mathrm{Ct}(\mathrm{RO})}$.

The DNA methylation (\%) was calculated as following:

hypermethylated DNA fraction (HM) = Rs/(R0-Rsd) x 100; unmethylated DNA fraction (UM) $=\mathrm{Rd} /(\mathrm{R} 0-\mathrm{Rsd})$ $x 100$; intermediately methylated DNA fraction (IM) $=1$-HM-UM. If or $\Delta \mathrm{Ct}(\mathrm{Rd}-\mathrm{RO})$ or $\Delta \mathrm{Ct}(\mathrm{Rs}-\mathrm{RO})<1.0$, The DNA methylation (\%) was calculate as following: $\mathrm{HM}=1-\mathrm{UM}, \mathrm{UM}=1-\mathrm{HM}^{76,77}$.

\section{Statistics}

GraphPad Prism Version 7.0 (GraphPad Software, La Jolla, CA, USA) was used to generate graphical figures and to perform statistical analysis. Data are expressed as the mean $\pm S D$. Statistical significance was defined as $*=P \leq 0.05, * *=P \leq 0.01, * * *=P \leq 0.001$.

\section{Abbreviations}

EMT: epithelial mesenchymal transition; 5-aza: 5-azacytidine; MSRE: methylation; sensitive restriction enzymes; MDRE: methylation dependent restriction enzymes; HM: hypermethylated DNA fraction; UM: unmethylated DNA fraction; IM: intermediately methylated DNA fraction; TSS: transcription start site.

\section{Declarations}




\section{Data Availability}

All data generated or analyzed during this study are included in the manuscript.

\section{Acknowledgments}

We thank Dr. Ibrahim Othman (General Director of the AECS), Dr. Nizar Mirali (Head of Department of Biotechnology in the AECS) for their support to complete this work.

\section{Authors' contributions}

YA and HM were responsible for the overall study design. YA. HM, CS, and AA performed the data analysis. YA, HM and CS drafted the paper. All authors read and approved the final manuscript.

\section{Funding}

Not applicable

\section{Competing interests}

The authors declare no competing interests

\section{References}

1. Torre, L. A. et al. Ovarian cancer statistics, 2018. CA

2. a cancer journal for clinicians 68, 284-296, doi:10.3322/caac.21456 (2018).

3. Motohara, T. \& Katabuchi, H. Ovarian Cancer Stemness

4. Biological and Clinical Implications for Metastasis and Chemotherapy Resistance. Cancers 11, doi:10.3390/cancers11070907 (2019).

5. Momenimovahed, Z., Tiznobaik, A., Taheri, S. \& Salehiniya, H. Ovarian cancer in the world

6. epidemiology and risk factors. International journal of women's health 11, 287-299, doi:10.2147/IJWH.S197604 (2019).

7. Raja, F. A., Chopra, N. \& Ledermann, J. A. Optimal first-line treatment in ovarian cancer. Annals of oncology

8. official journal of the European Society for Medical Oncology 23 Suppl 10, x118-127, doi:10.1093/annonc/mds315 (2012).

9. Ghosh, S. Cisplatin

10. The first metal based anticancer drug. Bioorganic chemistry $\mathbf{8 8}, 102925$, doi:10.1016/j.bioorg.2019.102925 (2019).

11. Rocha, C. R. R., Silva, M. M., Quinet, A., Cabral-Neto, J. B. \& Menck, C. F. M. DNA repair pathways and cisplatin resistance

12. an intimate relationship. Clinics 73, e478s, doi:10.6061/clinics/2018/e478s (2018). 
13. Roos, W. P. \& Kaina, B. DNA damage-induced cell death by apoptosis. Trends in molecular medicine $12,440-450$, doi

14. 1016/j.molmed.2006.07.007 (2006).

15. Florea, A. M. \& Busselberg, D. Cisplatin as an anti-tumor drug

16. cellular mechanisms of activity, drug resistance and induced side effects. Cancers 3, 1351-1371, doi:10.3390/cancers3011351 (2011).

17. Bukowski, K., Kciuk, M. \& Kontek, R. Mechanisms of Multidrug Resistance in Cancer Chemotherapy. International journal of molecular sciences 21, doi

18. 3390/ijms21093233 (2020).

19. Assaraf, Y. G. et al. The multi-factorial nature of clinical multidrug resistance in cancer. Drug resistance updates

20. reviews and commentaries in antimicrobial and anticancer chemotherapy 46, 100645, doi:10.1016/j.drup.2019.100645 (2019).

21. Gloushankova, N. A., Zhitnyak, I. Y. \& Rubtsova, S. N. Role of Epithelial-Mesenchymal Transition in Tumor Progression. Biochemistry. Biokhimiia 83, 1469-1476, doi

22. 1134/S0006297918120052 (2018).

23. De Craene, B. \& Berx, G. Regulatory networks defining EMT during cancer initiation and progression. Nature reviews. Cancer 13, 97-110, doi

24. $1038 / \operatorname{nrc3} 447$ (2013).

25. Heerboth, S. et al. EMT and tumor metastasis. Clinical and translational medicine 4, 6, doi 26. 1186/s40169-015-0048-3 (2015).

27. Wang, X. et al. Cisplatin resistance in gastric cancer cells is involved with GPR30-mediated epithelialmesenchymal transition. Journal of cellular and molecular medicine 24, 3625-3633, doi

28. 1111/jcmm. 15055 (2020).

29. He, Y., Xie, H., Yu, P., Jiang, S. \& Wei, L. FOXC2 promotes epithelial-mesenchymal transition and cisplatin resistance of non-small cell lung cancer cells. Cancer chemotherapy and pharmacology $\mathbf{8 2}$, 1049-1059, doi

30. 1007/s00280-018-3697-2 (2018).

31. Shen, M. et al. Inhibition of ATM reverses EMT and decreases metastatic potential of cisplatinresistant lung cancer cells through JAK/STAT3/PD-L1 pathway. Journal of experimental \& clinical cancer research

32. $C R 38,149$, doi:10.1186/s13046-019-1161-8 (2019).

33. Li, S. et al. Hippo pathway contributes to cisplatin resistant-induced EMT in nasopharyngeal carcinoma cells. Cell cycle 16, 1601-1610, doi

34. 1080/15384101.2017.1356508 (2017).

35. Zhang, W. et al. Chemoresistance to 5-fluorouracil induces epithelial-mesenchymal transition via upregulation of Snail in MCF7 human breast cancer cells. Biochemical and biophysical research 
communications 417, 679-685, doi

36. 1016/j.bbrc.2011.11.142 (2012).

37. Iseri, O. D. et al. Drug resistant MCF-7 cells exhibit epithelial-mesenchymal transition gene expression pattern. Biomedicine \& pharmacotherapy = Biomedecine \& pharmacotherapie 65, 40-45, doi

38. 1016/j.biopha.2010.10.004 (2011).

39. Du, F. et al. Acquisition of paclitaxel resistance via PI3Kdependent epithelialmesenchymal transition in A2780 human ovarian cancer cells. Oncology reports $30,1113-1118$, doi

40. 3892/or.2013.2567 (2013).

41. Kajiyama, H. et al. Chemoresistance to paclitaxel induces epithelial-mesenchymal transition and enhances metastatic potential for epithelial ovarian carcinoma cells. International journal of oncology 31, 277-283 (2007).

42. Han, X. et al. A Feedback Loop Between miR-30a/c-5p and DNMT1 Mediates Cisplatin Resistance in Ovarian Cancer Cells. Cellular physiology and biochemistry: international journal of experimental cellular physiology, biochemistry, and pharmacology 41, 973-986, doi:10.1159/000460618 (2017).

43. Boettcher, M., Kischkel, F. \& Hoheisel, J. D. High-definition DNA methylation profiles from breast and ovarian carcinoma cell lines with differing doxorubicin resistance. PloS one 5, e11002, doi:10.1371/journal.pone.0011002 (2010).

44. Yang, C. et al. Histone methyltransferase and drug resistance in cancers. Journal of experimental \& clinical cancer research: CR 39, 173, doi:10.1186/s13046-020-01682-z (2020).

45. Moore, L. D., Le, T. \& Fan, G. DNA methylation and its basic function. Neuropsychopharmacology: official publication of the American College of Neuropsychopharmacology 38, 23-38, doi:10.1038/npp.2012.112 (2013).

46. Esteller, M. CpG island hypermethylation and tumor suppressor genes: a booming present, a brighter future. Oncogene 21, 5427-5440, doi:10.1038/sj.onc.1205600 (2002).

47. Rauluseviciute, I., Drablos, F. \& Rye, M. B. DNA hypermethylation associated with upregulated gene expression in prostate cancer demonstrates the diversity of epigenetic regulation. BMC medical genomics 13, 6, doi:10.1186/s12920-020-0657-6 (2020).

48. Romero-Garcia, S., Prado-Garcia, H. \& Carlos-Reyes, A. Role of DNA Methylation in the Resistance to Therapy in Solid Tumors. Frontiers in oncology 10, 1152, doi:10.3389/fonc.2020.01152 (2020).

49. Shen, L. et al. Drug sensitivity prediction by $\mathrm{CpG}$ island methylation profile in the $\mathrm{NCl}-60$ cancer cell line panel. Cancer research 67, 11335-11343, doi:10.1158/0008-5472.CAN-07-1502 (2007).

50. Galle, E. et al. DNA methylation-driven EMT is a common mechanism of resistance to various therapeutic agents in cancer. Clinical epigenetics 12, 27, doi:10.1186/s13148-020-0821-z (2020).

51. Zeller, C. et al. Candidate DNA methylation drivers of acquired cisplatin resistance in ovarian cancer identified by methylome and expression profiling. Oncogene 31, 4567-4576, doi:10.1038/onc.2011.611 (2012). 
52. Lund, R. J. et al. DNA methylation and Transcriptome Changes Associated with Cisplatin Resistance in Ovarian Cancer. Scientific reports 7, 1469, doi:10.1038/s41598-017-01624-4 (2017).

53. Medarova, Z., Pantazopoulos, P. \& Yoo, B. Screening of potential miRNA therapeutics for the prevention of multi-drug resistance in cancer cells. Scientific reports 10, 1970, doi:10.1038/s41598020-58919-2 (2020).

54. Kibria, G., Hatakeyama, H., Akiyama, K., Hida, K. \& Harashima, H. Comparative study of the sensitivities of cancer cells to doxorubicin, and relationships between the effect of the drug-efflux pump P-gp. Biological \& pharmaceutical bulletin 37, 1926-1935, doi:10.1248/bpb.b14-00529 (2014).

55. Mohri, M., Nitta, H. \& Yamashita, J. Expression of multidrug resistance-associated protein (MRP) in human gliomas. Journal of neuro-oncology 49, 105-115, doi:10.1023/a:1026528926482 (2000).

56. Januchowski, R. et al. Drug transporter expression profiling in chemoresistant variants of the $A 2780$ ovarian cancer cell line. Biomedicine \& pharmacotherapy = Biomedecine \& pharmacotherapie 68, 447-453, doi:10.1016/j.biopha.2014.02.002 (2014).

57. Januchowski, R., Wojtowicz, K., Sujka-Kordowska, P., Andrzejewska, M. \& Zabel, M. MDR gene expression analysis of six drug-resistant ovarian cancer cell lines. BioMed research international 2013, 241763, doi:10.1155/2013/241763 (2013).

58. Januchowski, R. et al. Analysis of MDR genes expression and cross-resistance in eight drug resistant ovarian cancer cell lines. Journal of ovarian research 9, 65, doi:10.1186/s13048-016-0278-z (2016).

59. Januchowski, R. et al. Microarray-based detection and expression analysis of new genes associated with drug resistance in ovarian cancer cell lines. Oncotarget 8, 49944-49958, doi:10.18632/oncotarget.18278 (2017).

60. Helleman, J. et al. Impaired cisplatin influx in an A2780 mutant cell line: evidence for a putative, cisconfiguration-specific, platinum influx transporter. Cancer biology \& therapy 5, 943-949, doi:10.4161/cbt.5.8.2876 (2006).

61. Ashrafizadeh, M. et al. Association of the Epithelial-Mesenchymal Transition (EMT) with Cisplatin Resistance. International journal of molecular sciences 21, doi:10.3390/ijms21114002 (2020).

62. Lamouille, S., Xu, J. \& Derynck, R. Molecular mechanisms of epithelial-mesenchymal transition. Nature reviews. Molecular cell biology 15, 178-196, doi:10.1038/nrm3758 (2014).

63. Sonego, M. et al. Common biological phenotypes characterize the acquisition of platinum-resistance in epithelial ovarian cancer cells. Scientific reports 7, 7104, doi:10.1038/s41598-017-07005-1 (2017).

64. Hou, L. et al. PD98059 impairs the cisplatin-resistance of ovarian cancer cells by suppressing ERK pathway and epithelial mesenchymal transition process. Cancer biomarkers: section A of Disease markers 21, 187-194, doi:10.3233/CBM-170644 (2017).

65. Liu, Y. et al. MicroRNA-20a contributes to cisplatin-resistance and migration of OVCAR3 ovarian cancer cell line. Oncology letters 14, 1780-1786, doi:10.3892/ol.2017.6348 (2017).

66. Boac, B. M. et al. Micro-RNAs associated with the evolution of ovarian cancer cisplatin resistance. Gynecologic oncology 140, 259-263, doi:10.1016/j.ygyno.2015.12.026 (2016). 
67. Hojo, N. et al. Snail knockdown reverses stemness and inhibits tumour growth in ovarian cancer. Scientific reports 8, 8704, doi:10.1038/s41598-018-27021-z (2018).

68. Byers, L. A. et al. An epithelial-mesenchymal transition gene signature predicts resistance to EGFR and PI3K inhibitors and identifies AxI as a therapeutic target for overcoming EGFR inhibitor resistance. Clinical cancer research: an official journal of the American Association for Cancer Research 19, 279-290, doi:10.1158/1078-0432.CCR-12-1558 (2013).

69. Ren, S. et al. Epithelial phenotype as a predictive marker for response to EGFR-TKIs in non-small cell lung cancer patients with wild-type EGFR. International journal of cancer 135, 2962-2971, doi:10.1002/ijc.28925 (2014).

70. Yauch, R. L. et al. Epithelial versus mesenchymal phenotype determines in vitro sensitivity and predicts clinical activity of erlotinib in lung cancer patients. Clinical cancer research: an official journal of the American Association for Cancer Research 11, 8686-8698, doi:10.1158/1078-0432.CCR-051492 (2005).

71. Miow, Q. H. et al. Epithelial-mesenchymal status renders differential responses to cisplatin in ovarian cancer. Oncogene 34, 1899-1907, doi:10.1038/onc.2014.136 (2015).

72. Oliveras-Ferraros, C. et al. Epithelial-to-mesenchymal transition (EMT) confers primary resistance to trastuzumab (Herceptin). Cell cycle 11, 4020-4032, doi:10.4161/cc.22225 (2012).

73. Biswas, K. H. \& Zaidel-Bar, R. Early events in the assembly of E-cadherin adhesions. Experimental cell research 358, 14-19, doi:10.1016/j.yexcr.2017.02.037 (2017).

74. Zhang, P. et al. Epithelial-mesenchymal transition is necessary for acquired resistance to cisplatin and increases the metastatic potential of nasopharyngeal carcinoma cells. International journal of molecular medicine 33, 151-159, doi:10.3892/ijmm.2013.1538 (2014).

75. Schnell, U., Cirulli, V. \& Giepmans, B. N. EpCAM: structure and function in health and disease. Biochimica et biophysica acta 1828, 1989-2001, doi:10.1016/j.bbamem.2013.04.018 (2013).

76. Huang, L. et al. Functions of EpCAM in physiological processes and diseases (Review). International journal of molecular medicine 42, 1771-1785, doi:10.3892/ijmm.2018.3764 (2018).

77. Woopen, H. et al. Overexpression of the epithelial cell adhesion molecule is associated with a more favorable prognosis and response to platinum-based chemotherapy in ovarian cancer. Journal of gynecologic oncology 25, 221-228, doi:10.3802/jgo.2014.25.3.221 (2014).

78. Puisieux, A., Brabletz, T. \& Caramel, J. Oncogenic roles of EMT-inducing transcription factors. Nature cell biology 16, 488-494, doi:10.1038/ncb2976 (2014).

79. Batlle, E. et al. The transcription factor snail is a repressor of E-cadherin gene expression in epithelial tumour cells. Nature cell biology 2, 84-89, doi:10.1038/35000034 (2000).

80. Bolos, V. et al. The transcription factor Slug represses E-cadherin expression and induces epithelial to mesenchymal transitions: a comparison with Snail and E47 repressors. Journal of cell science 116, 499-511, doi:10.1242/jcs.00224 (2003).

81. Xu, R., Won, J. Y., Kim, C. H., Kim, D. E. \& Yim, H. Roles of the Phosphorylation of Transcriptional Factors in Epithelial-Mesenchymal Transition. Journal of oncology 2019, 5810465, 
doi:10.1155/2019/5810465 (2019).

82. Li, X. et al. Role of TWIST2, E-cadherin and Vimentin in epithelial ovarian carcinogenesis and prognosis and their interaction in cancer progression. European journal of gynaecological oncology 37, 100-108 (2016).

83. Mao, Y. et al. The role of nuclear beta-catenin accumulation in the Twist2-induced ovarian cancer EMT. PloS one 8, e78200, doi:10.1371/journal.pone.0078200 (2013).

84. Wang, T. et al. Twist2 contributes to cisplatin-resistance of ovarian cancer through the AKT/GSK3beta signaling pathway. Oncology letters 7, 1102-1108, doi:10.3892/ol.2014.1816 (2014).

85. Sandoval, J. \& Esteller, M. Cancer epigenomics: beyond genomics. Current opinion in genetics \& development 22, 50-55, doi:10.1016/j.gde.2012.02.008 (2012).

86. Carmona, F. J. et al. A comprehensive DNA methylation profile of epithelial-to-mesenchymal transition. Cancer research 74, 5608-5619, doi:10.1158/0008-5472.CAN-13-3659 (2014).

87. McDonald, O. G., Wu, H., Timp, W., Doi, A. \& Feinberg, A. P. Genome-scale epigenetic reprogramming during epithelial-to-mesenchymal transition. Nature structural \& molecular biology 18, 867-874, doi:10.1038/nsmb.2084 (2011).

88. Chang, X. et al. Identification of hypermethylated genes associated with cisplatin resistance in human cancers. Cancer research 70, 2870-2879, doi:10.1158/0008-5472.CAN-09-3427 (2010).

89. van der Gun, B. T. et al. Transcription factors and molecular epigenetic marks underlying EpCAM overexpression in ovarian cancer. British journal of cancer 105, 312-319, doi:10.1038/bjc.2011.231 (2011).

90. Spizzo, G. et al. Methylation status of the Ep-CAM promoter region in human breast cancer cell lines and breast cancer tissue. Cancer letters 246, 253-261, doi:10.1016/j.canlet.2006.03.002 (2007).

91. van der Gun, B. T. F. et al. Persistent downregulation of the pancarcinoma-associated epithelial cell adhesion molecule via active intranuclear methylation. International journal of cancer 123, 484-489, doi:10.1002/ijc.23476 (2008).

92. Serrano-Gomez, S. J., Maziveyi, M. \& Alahari, S. K. Regulation of epithelial-mesenchymal transition through epigenetic and post-translational modifications. Molecular cancer 15, 18, doi:10.1186/s12943-016-0502-x (2016).

93. Chen, Y., Wang, K., Qian, C. N. \& Leach, R. DNA methylation is associated with transcription of Snail and Slug genes. Biochemical and biophysical research communications 430, 1083-1090, doi:10.1016/j.bbrc.2012.12.034 (2013).

94. Zhao, C. et al. TWIST2: A new candidate tumor suppressor in prostate cancer. The Prostate 79, 16471657, doi:10.1002/pros.23889 (2019).

95. Galvan, J. A. et al. TWIST1 and TWIST2 promoter methylation and protein expression in tumor stroma influence the epithelial-mesenchymal transition-like tumor budding phenotype in colorectal cancer. Oncotarget 6, 874-885, doi:10.18632/oncotarget.2716 (2015).

96. Holemon, $\mathrm{H}$. et al. MethylScreen: DNA methylation density monitoring using quantitative PCR. BioTechniques 43, 683-693, doi:10.2144/000112597 (2007). 
97. Ordway, J. M. et al. Comprehensive DNA methylation profiling in a human cancer genome identifies novel epigenetic targets. Carcinogenesis 27, 2409-2423, doi:10.1093/carcin/bgl161 (2006).

\section{Tables}

Table 1: Primer sequences used for quantitative real-time PCR in this study.

\begin{tabular}{|c|c|}
\hline \multirow{3}{*}{\begin{tabular}{|l} 
Gene symbol \\
MDR1
\end{tabular}} & Primers sequence (5'-3') \\
\hline & F- GAGGGGATGGTCAGTGTTGATGG \\
\hline & R-ATCGTGGTGGCAAACAATACAGGT \\
\hline \multirow[t]{2}{*}{ MRP1 } & F- CTCCTGTGGCTGAATCTGGGC \\
\hline & R-AGCACTTTGATCCCATTGAGAATTTCG \\
\hline \multirow[t]{2}{*}{$M R P 2$} & F- CCTGGGAACATGATTCGGAAGCC \\
\hline & R- GGAGGATTTCCCAGAGCCGAC \\
\hline \multirow[t]{2}{*}{$C D H 1$} & F- GTGGGCCAGGAAATCACATCCTA \\
\hline & R- GTTGGCAGTGTCTCTCCAAATCC \\
\hline \multirow[t]{2}{*}{ EPCAM } & F-GCCGCAGCTCAGGAAGAATGTG \\
\hline & R-CAACTGAAGTACACTGGCATTGACG \\
\hline \multirow{2}{*}{ SNAIL } & F-TGCAGGACTCTAATCCAGAGTTTACC \\
\hline & R- GGTGGGATGGCTGCCAGC \\
\hline \multirow[t]{2}{*}{ TWIST2 } & F-CAAGCTGAGCAAGATCCAGACGC \\
\hline & R-GGTCATCTTATTGTCCATCTCGTCG \\
\hline \multirow[t]{2}{*}{$G A P D H$} & F-ATGACCCCTTCATTGACC \\
\hline & R- GAAGATGGTGAT \\
\hline
\end{tabular}

Table 2: Primer sequences used for methylation study using methylscreen method. 


\begin{tabular}{|c|c|c|c|c|}
\hline $\begin{array}{l}\text { Gene } \\
\text { symbol }\end{array}$ & $\begin{array}{l}\text { Number of } \\
\text { CpGs and their } \\
\text { locations }\end{array}$ & $\begin{array}{l}\text { Product } \\
\text { size }\end{array}$ & $\begin{array}{l}\text { Number of } \\
\text { enzymes } \\
\text { restriction sites }\end{array}$ & Primers sequence (5'-3') \\
\hline \multirow[t]{2}{*}{ CDH1 } & \multirow{2}{*}{$\begin{array}{c}17 \mathrm{CpGs} \\
-306 \text { to }-82\end{array}$} & \multirow[t]{2}{*}{$224 \mathrm{bp}$} & \multirow{2}{*}{$\begin{array}{c}7 \text { Acil } \\
1 \text { Hpa1 } \\
7 \text { MCrBc }\end{array}$} & F-CAACTCCAGGCTAGAGGGTCAC \\
\hline & & & & $\begin{array}{l}\text { R- } \\
\text { ACTTCCGCAAGCTCACAGGTGC }\end{array}$ \\
\hline \multirow[t]{2}{*}{$E P C A M$} & \multirow{2}{*}{$\begin{array}{c}18 \text { CpGs } \\
-465 \text { to }-276\end{array}$} & \multirow[t]{2}{*}{189 bp } & \multirow{2}{*}{$\begin{array}{c}8 \text { Acil } \\
4 \text { Hha1 } \\
7 \text { MCrBc }\end{array}$} & $\begin{array}{l}\text { F- } \\
\text { CTCCTCGGAGGCCACCAAAGAT }\end{array}$ \\
\hline & & & & $\begin{array}{l}\text { R- } \\
\text { CCGCTGGTGCTCGTTGATGAGT }\end{array}$ \\
\hline \multirow[t]{3}{*}{ SNAIL } & \multirow{3}{*}{$\begin{array}{c}65 \text { CpGs } \\
-688 \text { to }-165\end{array}$} & \multirow[t]{3}{*}{523 bp } & \multirow{3}{*}{$\begin{array}{c}15 \text { Acil } \\
13 \text { Hha1 } \\
19 \text { MCrBc }\end{array}$} & F-AGAGGGCAGGGGTCTTCA \\
\hline & & & & \\
\hline & & & & R-ATTCGCGCAGCAGTAGCGCA \\
\hline \multirow[t]{2}{*}{ TWIST2 } & \multirow{2}{*}{$\begin{array}{c}15 \text { CpGs } \\
-328 \text { to }-177\end{array}$} & \multirow[t]{2}{*}{$151 \mathrm{bp}$} & \multirow{2}{*}{$\begin{array}{c}6 \text { Acil } \\
3 \text { Hhal } \\
4 \mathrm{MCrBc}\end{array}$} & $\begin{array}{l}\text { F- } \\
\text { CCGAAGGGGGAGGCAAAACTGA }\end{array}$ \\
\hline & & & & $\begin{array}{l}\text { R- } \\
\text { ACTCTAGCTGGGCTGGGTTGCT }\end{array}$ \\
\hline
\end{tabular}

Figures 

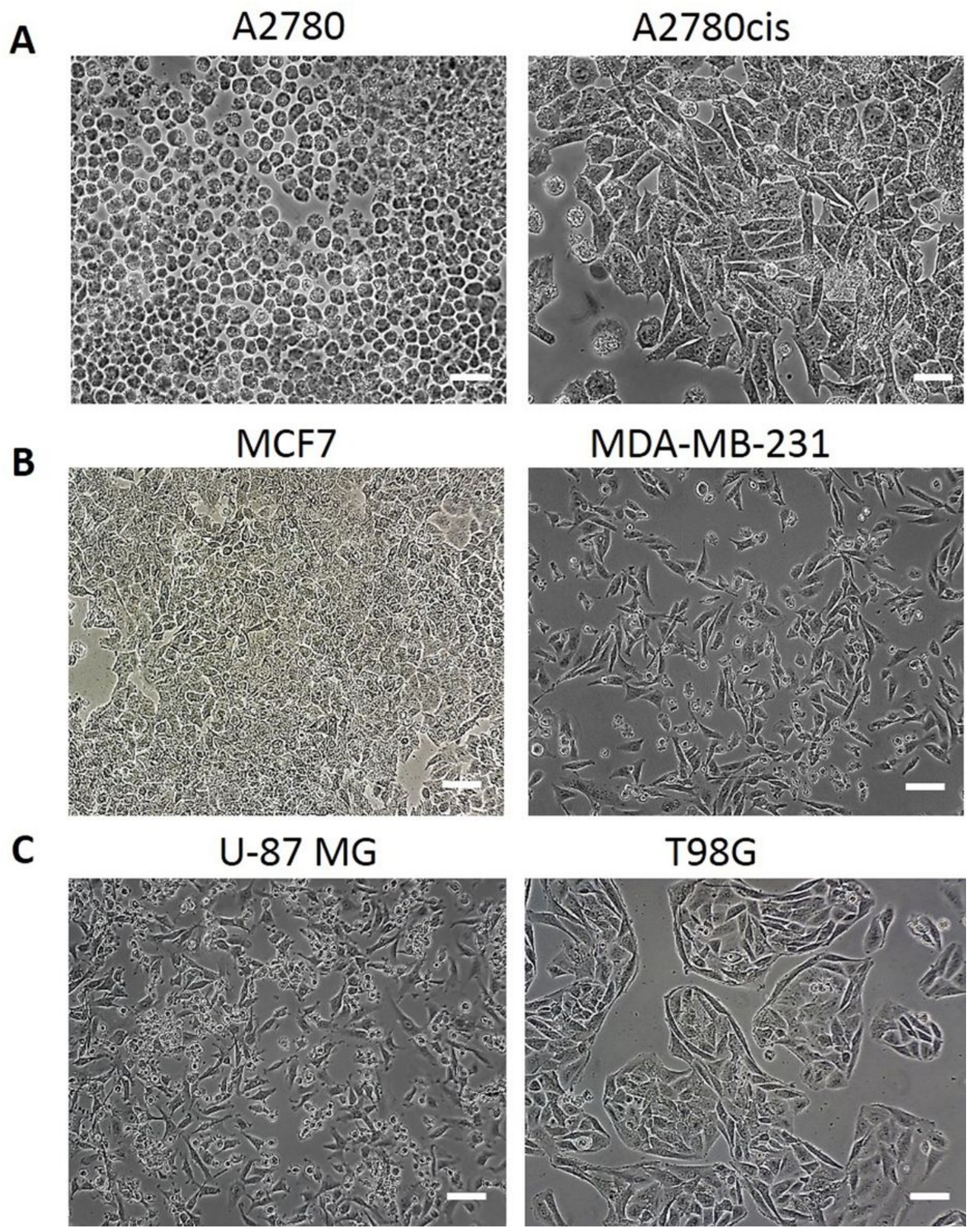

\section{T98G}

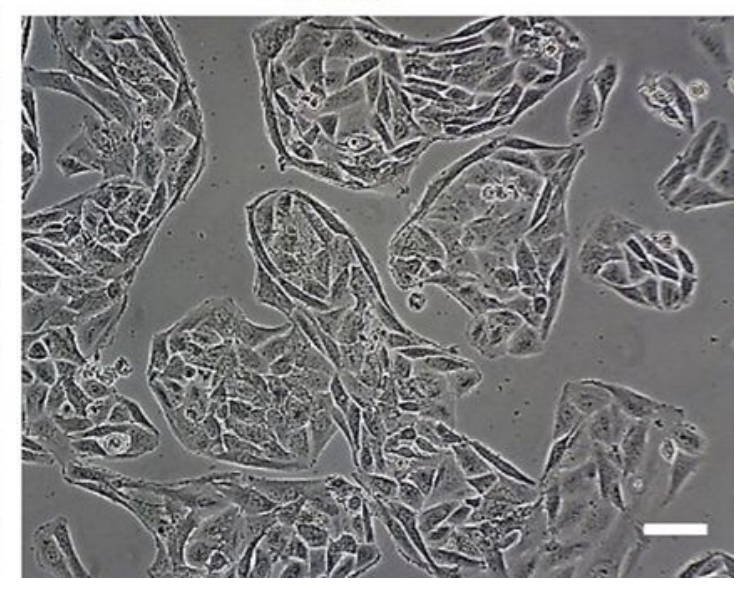

Figure 1

Cancer cell lines display morphological changes associated with EMT. (A) A2780 cells showed small round-shaped cells consistent with an epithelial phenotype and A2780cis exhibit larger, more elongated shaped cells. (B) MCF7 cells showed squamous epithelial cell shape and MDA-MB-231 exhibit spindle-like morphology. (C) U-87 MG and T98G cells exhibit spindle like. Scale bar=50 $\mu \mathrm{m}$. morphology, T98G showed 
a larger and more elongated cell shape compared to U-87 MG. (D) IC50 values for the studied cancer cell line.

A

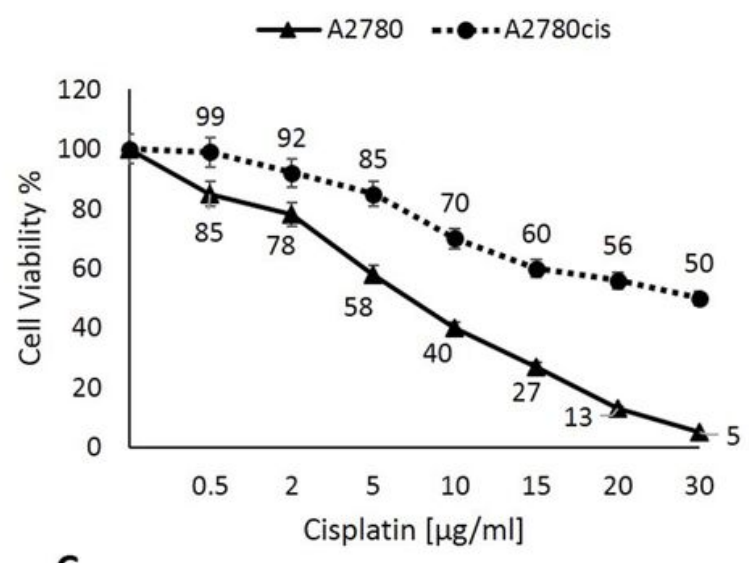

C

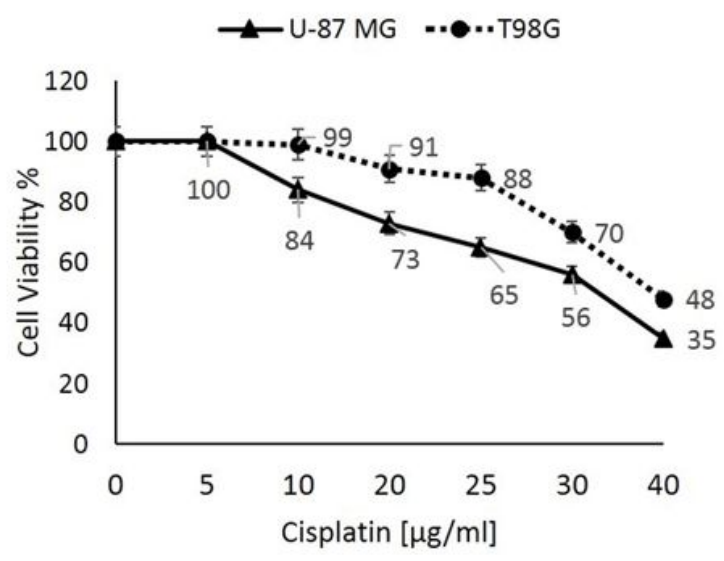

B

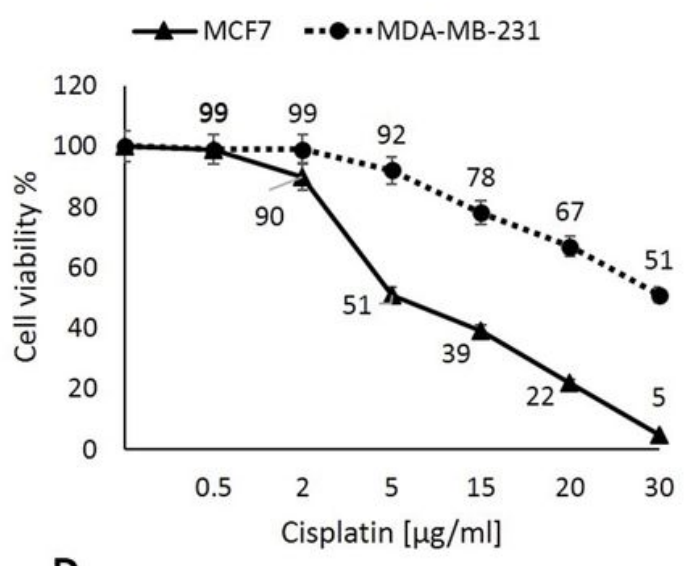

D

\begin{tabular}{lcc}
\hline Cancer Cell Line & Origin & IC $_{50}$ value \\
\hline A2780 & Ovarian cancer & $5 \mu \mathrm{g} / \mathrm{ml}$ \\
\hline A2780cis & Ovarian cancer & $30 \mu \mathrm{g} / \mathrm{ml}$ \\
MCF7 & Breast cancer & $5 \mu \mathrm{g} / \mathrm{ml}$ \\
\hline MDA-MB-231 & Breast cancer & $30 \mu \mathrm{g} / \mathrm{ml}$ \\
U-87 MG & Glioma & $30 \mu \mathrm{g} / \mathrm{ml}$ \\
\hline T98G & Glioma & $40 \mu \mathrm{g} / \mathrm{ml}$ \\
\hline
\end{tabular}

Figure 2

Cancer cells exhibit different resistance to cisplatin-induced cytotoxicity. (A): A2780 and A2780cis cells. (B): MCF7 and MDA-MB-231 cells. (C) U-87 MG and T98G cells. 


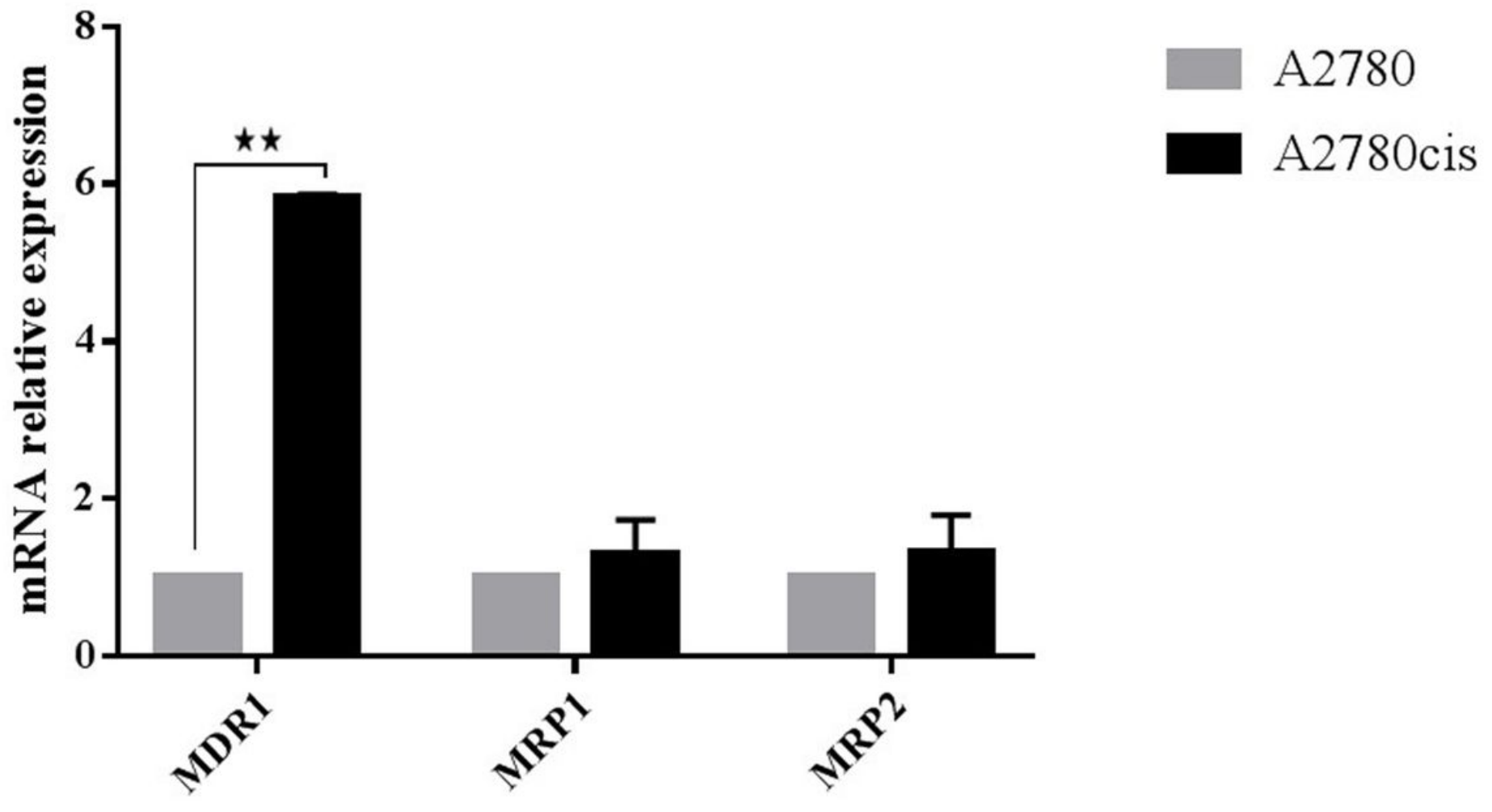

Figure 3

qPCR analysis of the MDR genes in A2780cis cells. MDR1 Expression increases in the resistant variant A2780cis cells. The expression levels were normalized to parental cells A2780.

A

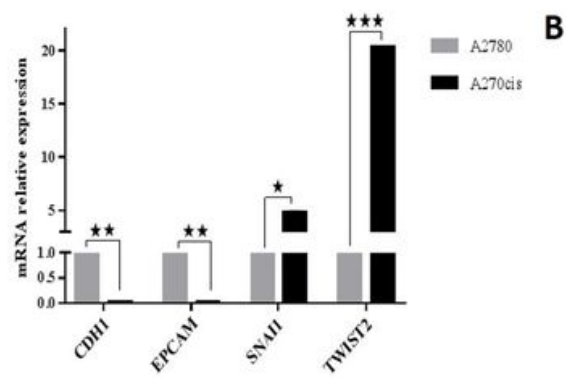

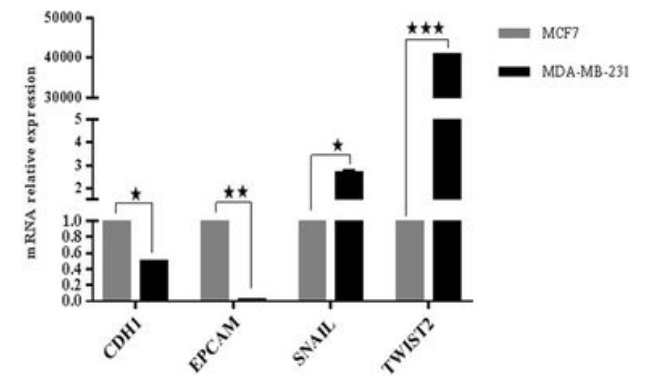

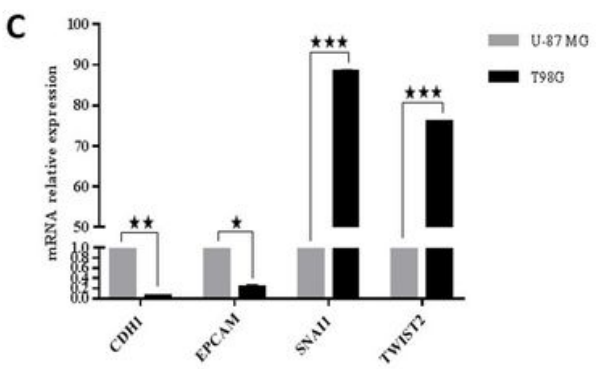

Figure 4

Resistant cancer cells display molecular changes consistent with EMT. Down-regulation in epithelial genes: $\mathrm{CDH} 1$ and EPCAM, and up-regulation in mesenchymal marker SNAIL and TWIST2, were assessed using qPCR. (A) A2780cis compered to parental cells A2780. (B) MDAMB-231 cisplatin resistant cells compared to MCF7 cisplatin sensitive cells. (C) T98G cisplatin resistant cells compared to U-87 MG the more sensitive cisplatin cells. 


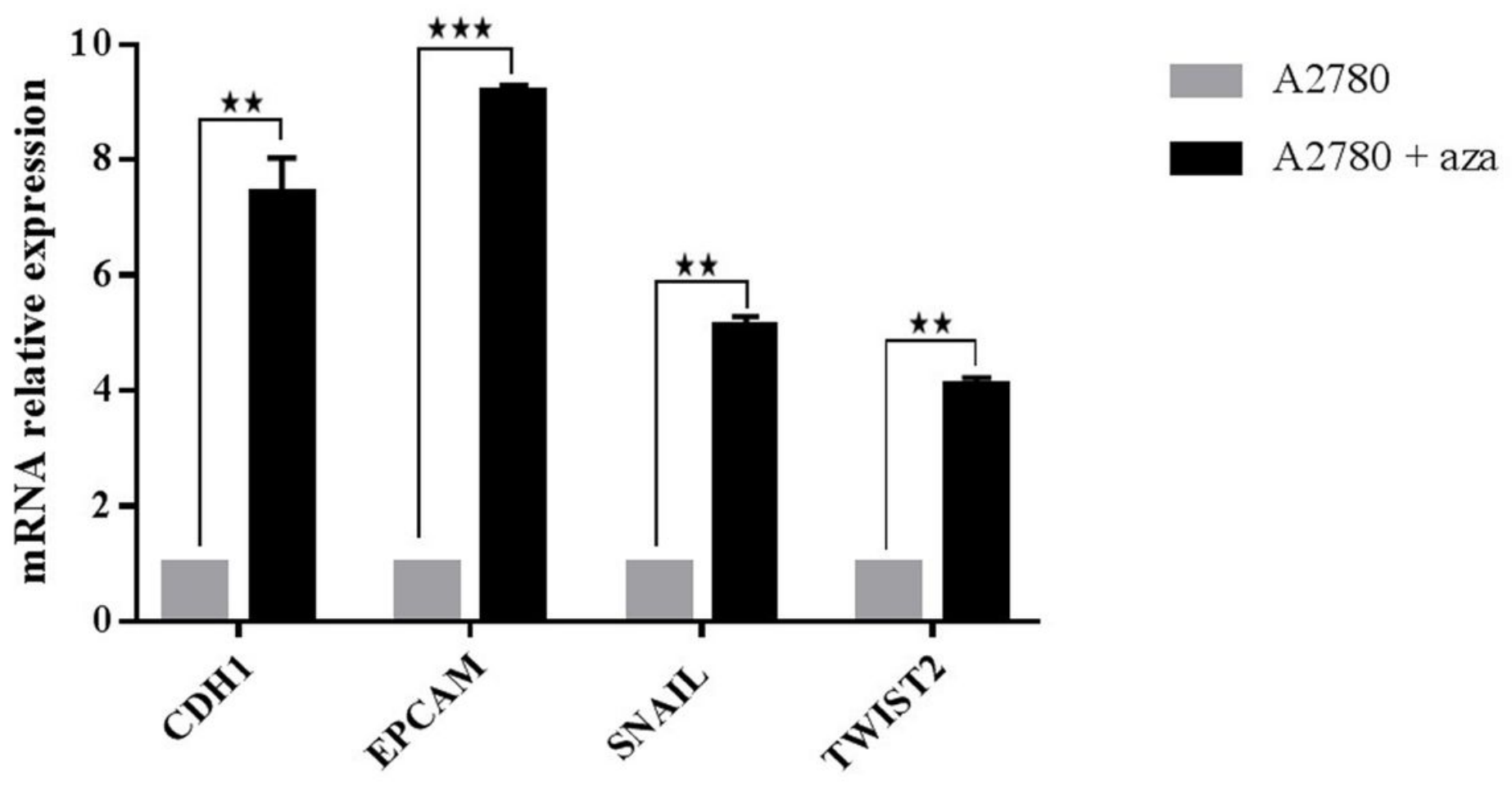

Figure 5

EMT marker gene expression changes after exposure to the demethylating agent 5-azacytidine. qPCR validation of gene expression showed a significant up-regulation of EMT genes in A2780 cells treated with azacytidine compared with control.

A $\quad C D H 1(-306$ to $-82 \mathrm{bp})$

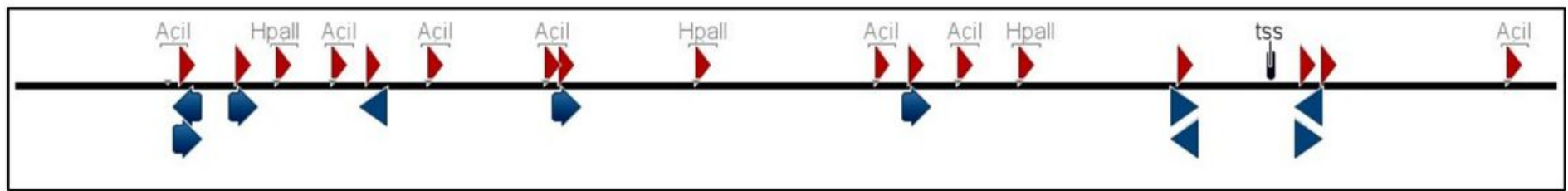

B

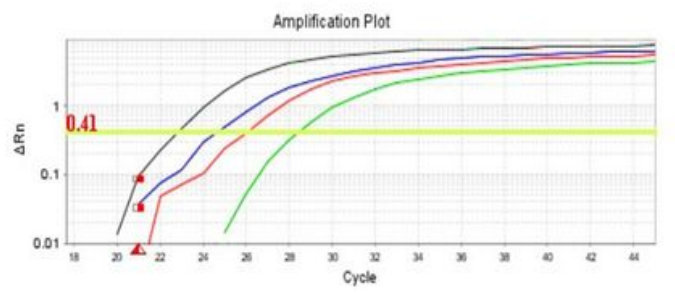

A2780cis

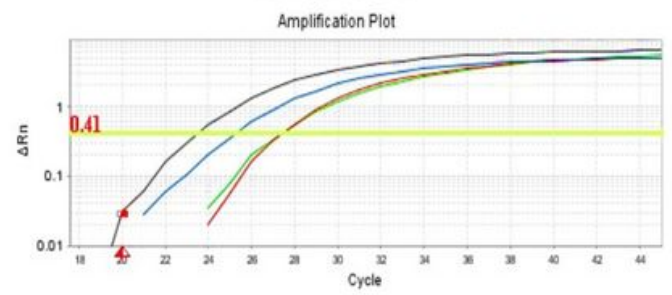

C

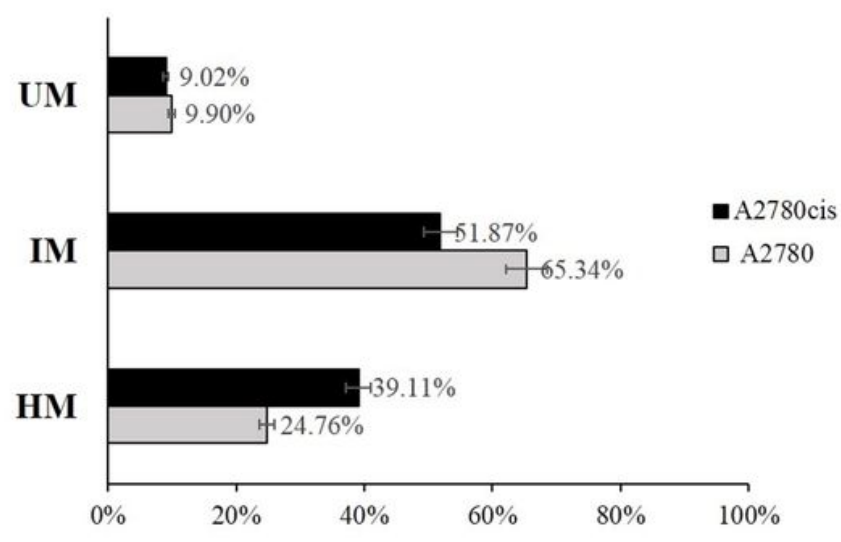




\section{Figure 6}

Methyscreen assay for $\mathrm{CDH} 1$ in $\mathrm{A} 2780$ and $\mathrm{A} 2780$ cis cell lines. (A) An illustration showing the studied section of $\mathrm{CDH} 1$ gene, $\mathrm{CpGs}$ dinucleotide are shown as red arrows, restriction sites of methylationsensitive enzymes MSRE are indicated as vertical domain, restriction sites of methylation-dependent enzymes MDRE shown as blue arrows. (B) The kinetic profiles obtained from $\mathrm{CDH} 1$ assay obtained from A2780 and A2780cis DNA are displayed. Each restricted genome's amplification is color coded by their treatment: mock restriction (black), MSRE restriction (blue), MDRE restriction (red) and a DD (green). (C) Charts display the result of EPCAM assay as a percentage of each portion of DNA.

\section{A $\operatorname{EPCAM}(-465$ to $-276 \mathrm{bp})$}

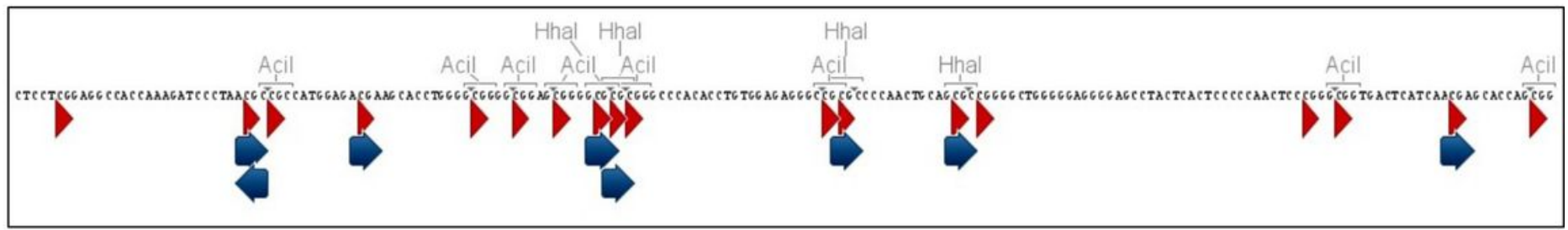

A2780

B

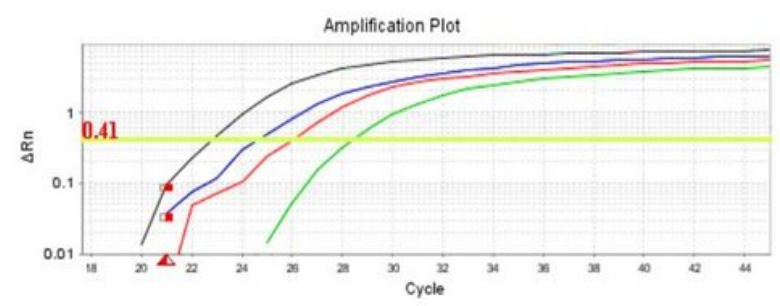

A2780cis

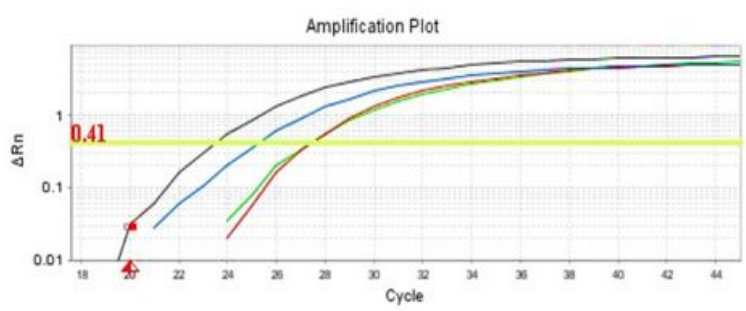

C

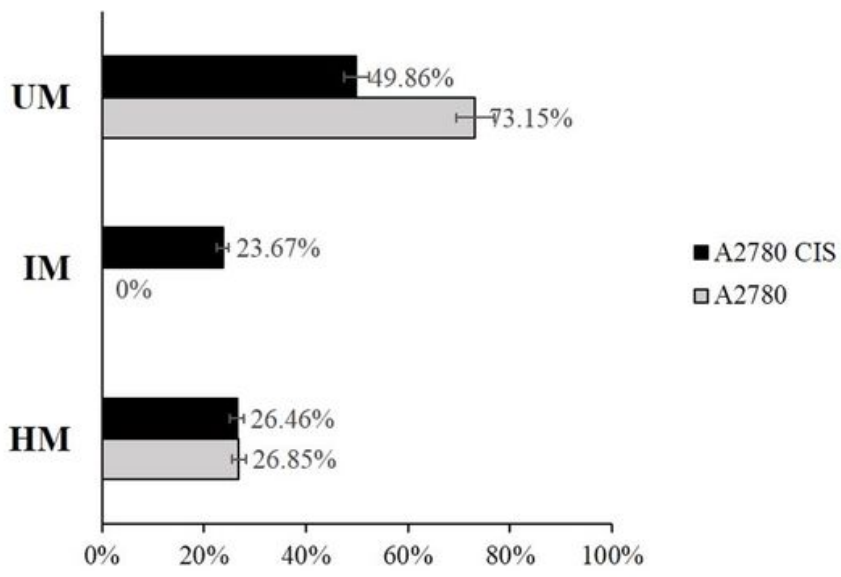

\section{Figure 7}

Methyscreen assay for EPCAM in A2780 and A2780cis cell lines. (A) An illustration showing the studied section of EPCAM gene, $\mathrm{CpGs}$ dinucleotide are shown as red arrows, restriction sites of methylationsensitive enzymes MSRE are indicated as vertical domain, restriction sites of methylation-dependent enzymes MDRE shown as blue arrows. (B) The kinetic profiles obtained from EPCAM assay obtained from A2780 and A2780cis DNA are displayed. Each restricted genome's amplification is color coded by their treatment: mock restriction (black), MSRE restriction (blue), MDRE restriction (red) and a DD (green). (C) Charts display the result of EPCAM assay as a percentage of each portion of DNA. 
A

Acil Acil

\section{A2780}

B

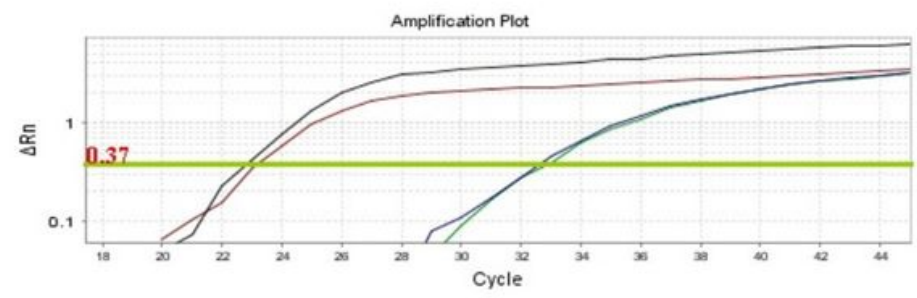

A2780cis

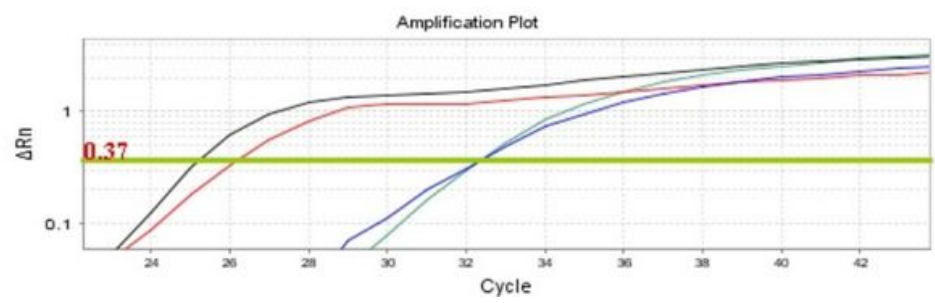

C

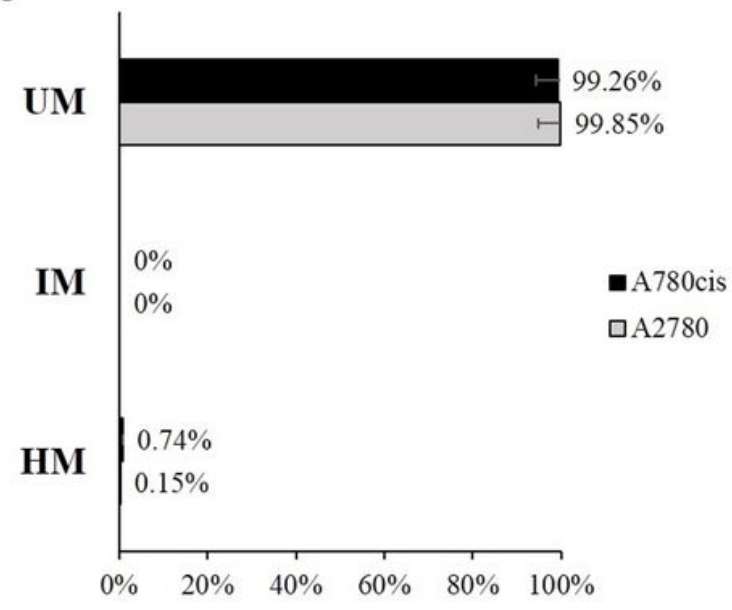

\section{Figure 8}

Methyscreen assay for SNAIL in A2780 and A2780cis cell lines. (A) An illustration showing the studied section of SNAIL gene, CpGs dinucleotide are shown as red arrows, restriction sites of methylationsensitive enzymes MSRE are indicated as vertical domain, restriction sites of methylation-dependent enzymes MDRE shown as blue arrows. (B) The kinetic profiles obtained from SNAIL assay obtained from A2780 and A2780cis DNA are displayed. Each restricted genome's amplification is color coded by their treatment: mock restriction (black), MSRE restriction (blue), MDRE restriction (red) and a DD (green). (C) Charts display the result of SNAIL assay as a percentage of each portion of DNA. 
A TWIST2(-328 to $-177 \mathrm{bp})$

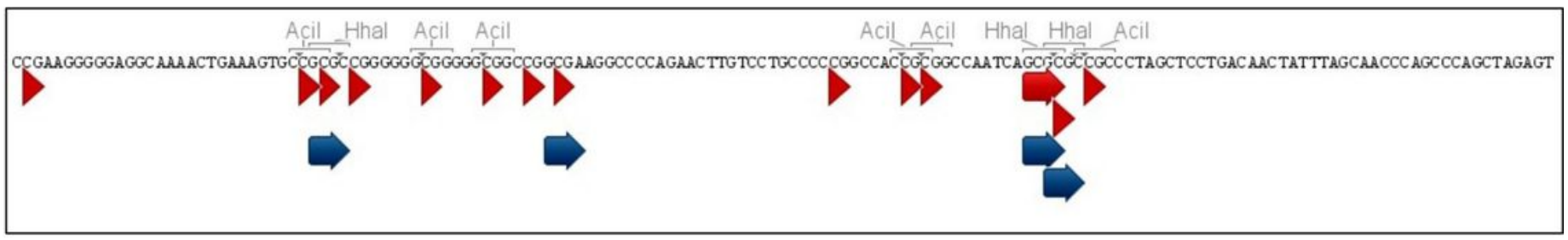

A2780

B

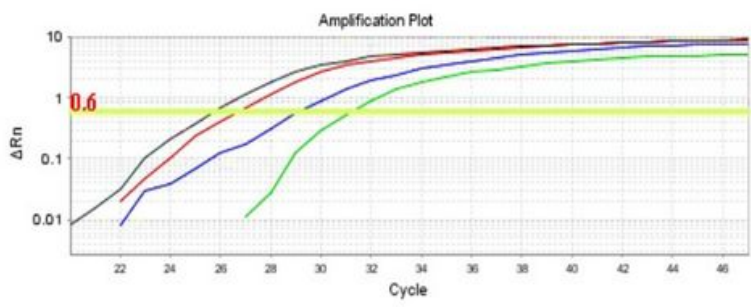

A2780cis

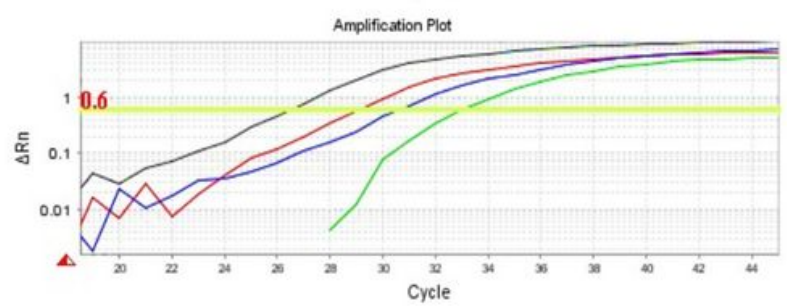

C

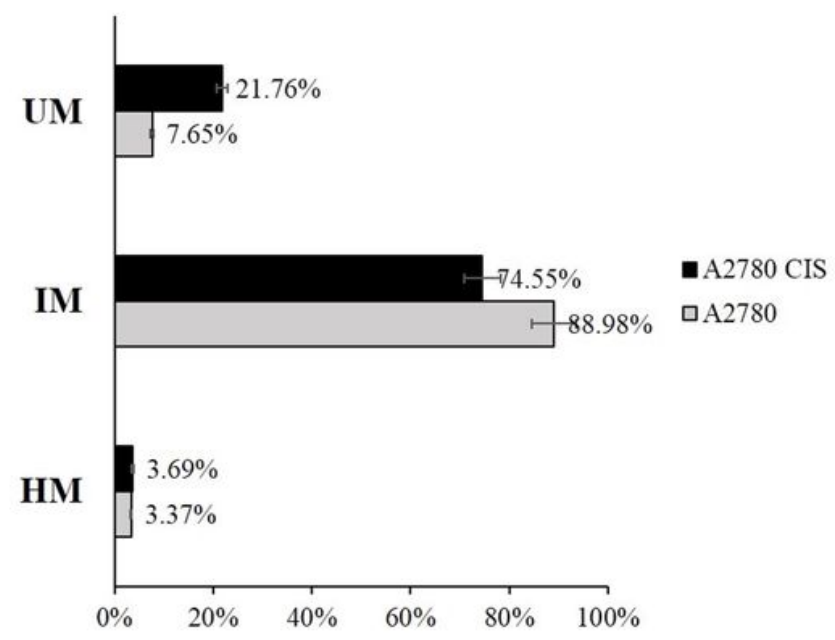

\section{Figure 9}

Methyscreen assay for TWIST2 in A2780 and A2780cis cell lines. (A) An illustration showing the studied section of TWIST2 gene, CpGs dinucleotide are shown as red arrows, restriction sites of methylationsensitive enzymes MSRE are indicated as vertical domain, restriction sites of methylation-dependent enzymes MDRE shown as blue arrows. (B) The kinetic profiles obtained from TWIST2 assay obtained from A2780 and A2780cis DNA are displayed. Each restricted genome's amplification is color coded by their treatment: mock restriction (black), MSRE restriction (blue), MDRE restriction (red) and a DD (green). (C) Charts display the result of TWIST2 assay as a percentage of each portion of DNA. 